\title{
Trends and Perspectives in Education for Sustainable Development in the Teaching of Geography in Spain
}

\author{
José Manuel Crespo Castellanos ${ }^{1, *}$, Ayar Rodríguez de Castro ${ }^{2, *}$ (D) and María Rosa Mateo Girona ${ }^{3, *}$ \\ 1 Department of Social Sciences, Experimental Sciences and Mathematics Didactics, Faculty of Education, \\ Complutense University of Madrid (UCM), 28040 Madrid, Spain \\ 2 Department of Education, Faculty of Health Sciences and Education, Distance University of Madrid (UDIMA), \\ 28400 Collado Villalba, Spain \\ 3 Department of Applied Didactics, Faculty of Education, Villanueva University, 28034 Madrid, Spain \\ * Correspondence: josemanuelcrespo@edu.ucm.es (J.M.C.C.); ayar-ventura.rodriguez@udima.es (A.R.d.C.); \\ RMateo@villanueva.edu (M.R.M.G.)
}

check for updates

Citation: Crespo Castellanos, J.M.; Rodríguez de Castro, A.; Mateo Girona, M.R. Trends and Perspectives in Education for Sustainable Development in the Teaching of Geography in Spain. Sustainability 2021, 13, 13118. https://doi.org/ $10.3390 /$ su132313118

Academic Editor: María Luisa de Lázaro y Torres

Received: 15 October 2021

Accepted: 23 November 2021

Published: 26 November 2021

Publisher's Note: MDPI stays neutral with regard to jurisdictional claims in published maps and institutional affiliations.

Copyright: (C) 2021 by the authors. Licensee MDPI, Basel, Switzerland. This article is an open access article distributed under the terms and conditions of the Creative Commons Attribution (CC BY) license (https:/ / creativecommons.org/licenses/by/ $4.0 /)$.

\begin{abstract}
The UN's Sustainable Development Goals (SDGs) should be known and assumed by the community of geography teachers in all levels of education as a key part of their educational work. In order for well-grounded SDGs-related geographic didactic proposals to be presented, and for researchers in didactics to find a way to incorporate and promote SDG-related contents in daily teaching, a thorough knowledge of the relevant geographical literature is mandatory. The aim of this work is to present the results of a review comprising 1183 papers submitted to the 22 congresses on the didactics of Geography organised by the Spanish Association of Geography working group in didactics from 1988 to 2019, as well as 186 works published in the only Spanish journal on the Didactics of Geography, Didáctica Geográfica. This analysis focuses on the contents addressed in these studies, as well as on the skills and didactic strategies related to the teaching of SDGs. It was found that most SDGs-related contributions in Spain deal with landscape and the environment. Regarding skills, it was concluded that much remains to be done concerning Education for Sustainable Development (ESD). Finally, the current and future role of ESD in geographical teaching in Spain is assessed.
\end{abstract}

Keywords: education for sustainable development; SDGs; didactics of geography; spanish association of geography; bibliographical analysis

\section{Introduction}

This work aims to analyse and assess research trends in the teaching of sustainable development in the field of geography in Spain, based on Spanish scientific production on the didactics of the discipline. Although this does not amount to a systematic bibliographic review, it can provide valuable information concerning the current status of research in geography didactics in Spain with regard to SDGs and, particularly, the urgent need for Education for Sustainable Development (ESD) to take a leading role in geography training in all educational levels.

With this work, we intend to answer several research questions regarding research in SDGs/ESD-related geography teaching in Spain:

RQ1-What are the main fields of interest of ESD-related research?

RQ2-What trends can be detected in ESD-related research in the field of geography?

RQ3 - What is the current role of ESD in geographical research in Spanish academia?

RQ4-What are the perspectives of ESD in the research field of the didactics of geography?

RQ5-What are the factors that explain the current and future role of ESD in geographical research?

Our research focuses on scientific production in Spain in order to evaluate the role of ESD as a field of geographical research in the country. Despite the relevant role played by 
geography in education, the field has little academic tradition in Spain. However, owing to the central part played by geography in ESD, we believe that an in-depth examination of Spanish research in the didactics of geography can contribute to assess the current position, trends and perspectives of ESD in our country.

For this purpose, the scientific production related to the Grupo de Didáctica de la Asociación Española de Geografía (Didactic working group of Spanish Association of Geography), the main academic association in the field of didactics of geography in Spain, was analysed in depth in order to establish the origins, trends and perspectives of research on ESD in Geography in Spain. This was done by analysing both the papers submitted to the 22 congresses on the didactics of geography organized by the working group from 1988 to 2019 and the manuscripts published in Didáctica Geográfica, the only Ibero-American journal focused exclusively on research on geography teaching. First, a comprehensive analysis of the state of ESD in Spain was undertaken, followed by a review of scientific publications using various bibliographic and bibliometric analytical tools. Finally, the main strengths and weaknesses of geography teaching in Spain in relation to ESD were identified, the main challenges outlined and a series of proposals for the future set forth.

\section{ESD in the Field of Geography}

For the purposes of this work, it was essential to have a clear idea of what is regarded to as ESDs in Spain, where geography is an idiosyncratic field, both as a discipline and in its academic trajectory, as we shall see shortly. First, a clear distinction must be made between Environmental Education (EE), the origin of the concern for didactics in the protection and preservation of the environment, and the more recent Education for Sustainable Development, the implications of which are much more specific. Following this, the role of geography education in ESDis outlined, and emphasis is laid on the potential of didactics in geography as a reference within ESD. Finally, the Spanish case is precisely contextualised, especially the evolution of geography education in Spain and the recent concern for ESD, as reflected in the Spanish scientific production in the field.

\subsection{From Environmental Education to Education for Sustainable Development}

We can date the beginning of environmental education to the 1960s, in relation to a series of events that highlighted the need for environmental education as a means for humans to reach an adequate balance with their environment. Some of these events took place in 1968, such as the creation in the United Kingdom of the Council for Environmental Education; the inclusion of EE in Swedish and French school curricula; and the compared study of the environment by UNESCO [1]. A few years later, the International Conference on Human Environment, Stockholm (1972), recommended the creation of a programme for the promotion of EE, which was regarded as a crucial step in the acquisition of the skills, attitudes and values necessary to address the global environmental crisis [2]. In 1975, the international seminar held in Belgrade by UNESCO and PNUMA launched the International Programme in Environmental Education. The Belgrade Charter presented the aims, targets and methods of EE. Two years later, the same organisations convened the first Intergovernmental Conference in Environmental Education in Tbilisi (1977), which established the theoretical corpus of this educational movement [3].

In 1987, the report Our Common Future, published by the World Commission on Environment and Development (Brundtland Report), defined sustainable development as "development that meets the needs of the present without compromising the ability of future generations to meet their own needs" [4]. Five years later, within the framework of the Earth Summit held in Rio de Janeiro, the Environmental Education Encounter, which resulted in the Treaty on Environmental Education for Sustainable Societies and Global Responsibility, highlighted EE's commitment to a new development model based on sustainability [3].

The UN's General Assembly, considering education as a crucial means for sustainable development, declared in 2005 the UN's Decade of Education for Sustainable Development 
(ESD), with UNESCO at the helm, stating that ESD "motivates, equips and involves individuals, and social groups in reflecting on how we currently live and work, in making informed decisions and creating ways to work towards a more sustainable world. ESD is about learning for change amongst adults as much as with youth" [5] in all walks of life. For this reason, it is not to be included in school curricula as an independent subject, but must be considered a "lateral, general proposal, and not an educational movement strictly speaking" [3]. We understand that ESD did not come to replace EE or other fields like education for peace, but to embrace it and project it [6].

\subsection{Contribution of Geography Education to ESD}

Within the field of Geography, in 1992, the Commission on Geography Education of the International Geographical Union (IGU) published the International Declaration on Geographical Education [7], which highlighted the contribution of geography education to environmental education and development. The International Declaration on Geographical Education and Cultural Diversity that followed in 2000 argued that "Geographical education offers foundations for people of the world to develop", among other things, "an appreciation of the urgent need to protect our environment and bring about environmental justice to local communities and regions that have experienced environmental devastation", as well as "an ability to act as an informed and active member of their own and the global society", emphasising that "Geographical education contributes to understanding the need to protect the natural environment at local, regional, national and international scales" [8]. Regarding the UN's Decade of Education for Sustainable Development 2005-2014 (UNDESD), it was viewed "as an opportunity to confirm its commitment to education for sustainable development" [9], and in 2007 the International Commission published the Lucerne Declaration on Geographical Education for Sustainable Development. This declaration revolved around three main issues: (1) the contribution of geography to ESD, because all the aspects highlighted by UNDESD have a geographical dimension, and therefore, sustainable development must be made part of geography teaching; (2) criteria to develop region- and country-sensitive ESD curricula; and (3) the importance of information and communication technologies (ICTs) in the teaching of ESD in geography, for they can contribute to the development of the necessary skills for lifelong learning and citizen engagement [9]. The Commission's fourth declaration, the International Declaration on Research in Geography Education in 2015 [10], points out the importance of research in geography education; and the fifth, the International Charter on Geography Education in 2016 [11], emphasises again geography's contribution to ESD: “Geography helps people to think critically about sustainable living locally and globally and how to act accordingly. Geography is much more than learning many facts and concepts. Its focus is on the patterns and processes that help us to understand an ever-changing planet" [11]. However, at the school level, geography has not yet fully assumed the role that these declarations demand with regard to ESD as a key contribution to the renewal of geography education for sustainable development [12].

The suitability of geography for ESD is reflected, among other things, in the curricula for different educational stages, "which coincide almost verbatim with the UN's Sustainable Development Targets" [13]. Geography's nature as a lateral (both social and environmental) discipline is at the very core of its value for the construction of sustainable societies [14]. Physical geography explains the operation of the Earth and its system from a holistic perspective of its subsystems: the atmosphere, the biosphere, the lithosphere, the hydrosphere and the edaphosphere. This understanding is crucial to apprehend the ongoing deterioration of natural systems and their global consequences. The teaching of human geography, on the other hand, addresses the dynamics and problems of human societies in relation to their territory. The combination of several geographical scales stimulates spatial empathy, revealing the dialectical relationships between facts and local and global flows [15]. 
Similarly, geography's teaching resources and methodologies encourage practical and experimental understanding, for instance with regard to the activities undertaken in the field [16-18]. The democratisation of Geographical Information Technologies (GIT) has made their use widespread in geography teaching, leading to hitherto unknown access to the interpretation of the Earth's surface and spatial phenomena [19], while facilitating the acquisition of digital skills that are increasingly necessary for lifelong learning. In conclusion, as pointed out by the Lucerne Declaration, geography teaching pursues the transmission of knowledge and the acquisition of necessary geographical skills for the understanding of the Earth and Human-Earth systems. This makes it eminently suitable for the development of a critical attitude towards local and global social and environmental issues.

In recognition of all this, this work aims to assess the current status of, and contributions from, Spanish geography to ESD. First, we must contextualise the current state of research in geography teaching in the country.

\subsection{Research on Geography Teaching in Spain}

As an independent academic research field, Geography is a newcomer to Spanish education. In contrast with other European countries, in which geography is a prestigious and fully consolidated subject, no independent Geography degrees were created in Spain until the 1993-94 academic year [20]. Previously, geography was taught as part of the Philosophy and Letters degree, and from 1973 it played a secondary role as a specialty in the Geography and History degree [21]. It is, therefore, unsurprising that scientific production in the field of geography was scarce, and next to non-existent concerning geography teaching, until well into the 1990s.

The Spanish Association of Geography (AGE), the key reference for Spanish academic geography (although one must not forget the Real Sociedad Geográfica, a society focused on geography research and dissemination, but whose interests are different to those of the AGE, which has closer links with academia), was founded in 1975 with the aim of "promoting scientific meetings, coordinating geography in its interaction with society, and cooperating with other national and international geographical associations" [22]. Despite the prominent role of the discipline in primary and secondary education and in lateral university degrees, geography teaching was initially not one of Spanish geography's main concerns, perhaps because of the urgent need to define the working and research fields, which was the discipline's first priority at the beginning.

Within the events and initiatives organised by the AGE, the first congress on geography teaching was held in 1988, a year after the formal creation of a working group on geography teaching. The group was organised at the initiative of several members who were concerned by a number of aspects that were directly related to the teaching of geography and expressed these concerns during the 1985 AGE's assembly in Murcia. The group's targets were, and are, to promote research-based innovation in geography teaching; to encourage methodological innovation in geography classrooms; and to stand as a didactic reference for teachers.

In 1996, the group launched the journal Didáctica Geográfica, which to date remains the only specialised Spanish research journal on geography teaching. It is worth pointing out that a journal with the same name was launched earlier, in 1977, at the University of Murcia, on the personal initiative of Prof. Pedro Plans Sanz de Bermond and some of his collaborators. The publication of this journal was interrupted in 1987 because of funding issues. The geography teaching group created within the AGE recovered the journal's name, with the support of the old journal's editors, extending its scope and making its publication more dynamic. Over the last 25 years, this publication has become a beacon for teachers of geography and associated disciplines in all educational levels, decisively contributing to advance research on geography teaching, along with the conferences on geography teaching convened periodically by the same group within AGE. In recent years, the group has made close ties with the Portuguese geographical association, and from 
2005 they organise joint Iberian conferences, which has increased the scope and impact of scientific production in this field in the Iberian Peninsula.

\section{Analysis and Assessment of Recent Research on Geography Teaching for ESD in Spain}

The bibliographical analysis to follow is limited to the papers published in the context of Spanish conferences on geography teaching and in the journal Didáctica Geográfica which most clearly express progress and trends in the field. An integrated analysis of the different topics broached in documents published between 1988 and 2019 in relation to sustainable education and teaching was undertaken. As previously noted, in this work we are exclusively dealing with scientific production in Spain, without taking into consideration the work of Spanish authors in international journals, as the purpose of the article is to establish and assess the role of ESD in geographical research undertaken within the framework of Spanish academic and scientific institutions.

\subsection{Materials and Methods}

This study is inspired by previous bibliometric research on ESD [23,24], but a different approach is adopted which takes into consideration the idiosyncrasy of the scientific production under analysis, which is not included in reference databases like WoS and Scopus, but which is a clear reflection of research approaches and interests in Spain and their evolution over time. Since this study deals with works published outside the purview of the reference databases noted above, a full bibliometric study has not been possible, but the analysis and cataloguing processes of Spanish geographic literature have been exhaustive, and the model of database used was particularly suited to our aims.

Several steps were taken to identify and analyse the relevant scientific production (Figure 1). First, all research linked to the teaching group in the AGE between 1988 and 2019 was catalogued; this included a total of 1183 contributions to the proceedings of the 22 conferences on geography teaching celebrated until 2019, and 186 papers published in the journal Didáctica Geográfica from 1996, when its publication began anew, to 2019. All the papers used are available in the Grupo de Didáctica de la Geografía de la AGE's website (http: / / www.age-geografia.es/didacticageografia/index.php? $\mathrm{m}=4$; accessed on 15 October 2021) and in the journal Didáctica Geográfica's website (https: / / didacticageografica. age-geografia.es/index.php/didacticageografica; accessed on 15 October 2021). Most of them are in Spanish (both the titles and the keywords were translated for this article), but there are also manuscripts in other languages (all of them can be consulted by checking the Supplementary Materials of the article).

Every item, author, title, keyword, publication title, place, year and other relevant metadata were entered into a primary database. The data were analysed through tag clouds (using WordSift and TagCrowd visualisers) in order to define the main fields of interest of Spanish geographical science, and filtered in order to identify those that primarily dealt with teaching and sustainability. Terms related to identifiers such as "sustainability" and "skills" were sought in paper titles and keywords as well as in the thematic lines emphasised by each of the 22 conferences. Only 50 contributions were found to be strictly related to sustainability (3.7\% of the total). Afterwards, these 50 works were examined in detail in order to evaluate their significance for the field of sustainability, and fourteen items were excluded, as they were found to be not strictly related with the teaching of sustainable development.

The remaining 36 publications, which are representative of research on sustainability teaching, were entered into the bibliographic reference manager RefWorks and exported and analysed in detail with the aid of bibliometric analysis software VOSviewer. This was used to analyse topic trends, based on titles and a on series of keywords defined during the detailed interpretive content analysis of every item (ten per document). Also, an analysis of the bibliographic interest of Spanish authors was conducted, using their bibliographies as reference. The analysis used word co-occurrence maps (titles, keywords and bibliographic 
references), and was visualised in RIS format; terminological recurrence can reveal trends among the authors of the AGE and their environment.

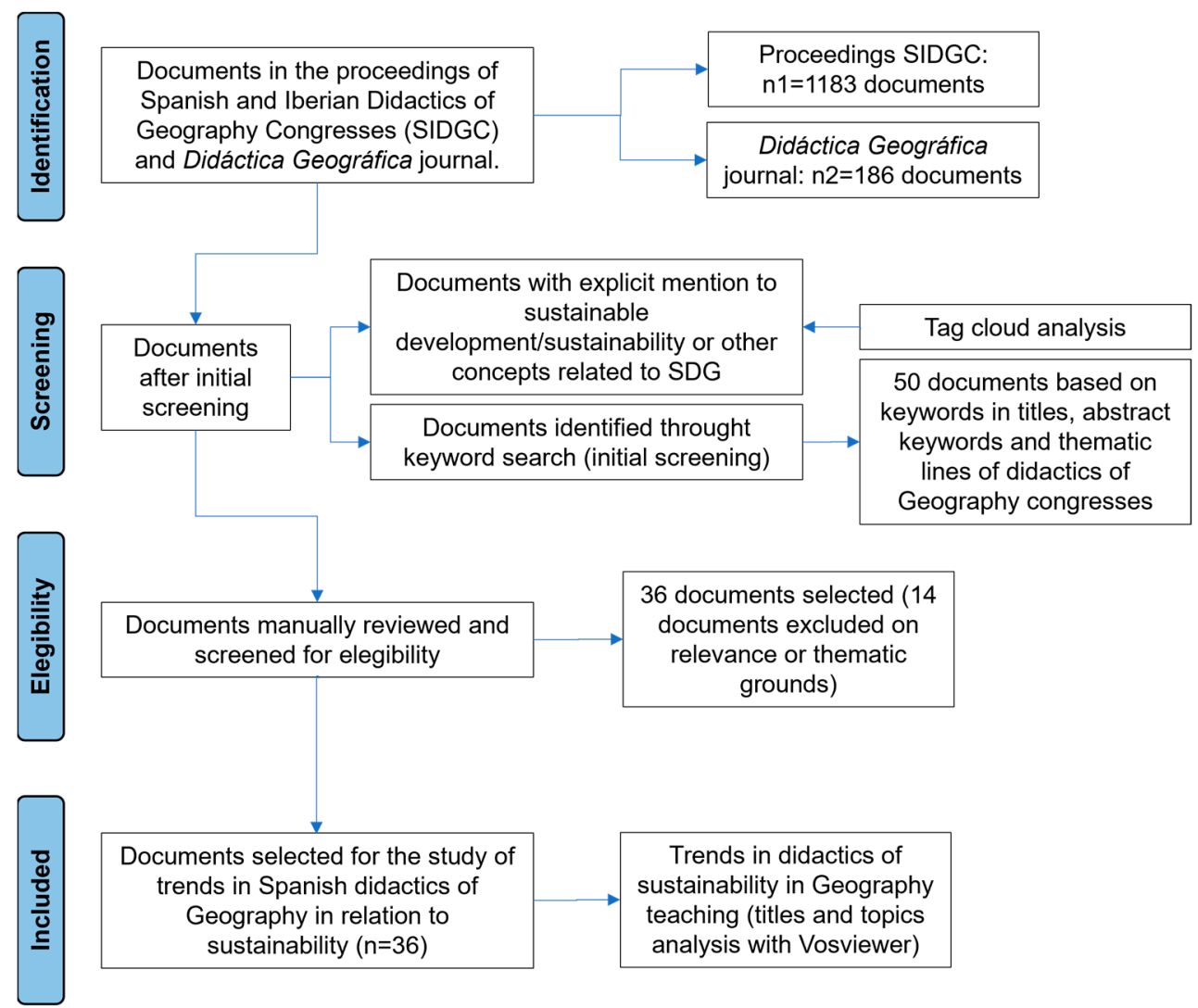

Figure 1. PRISMA flow diagram that illustrates the selection process of the documents used to analyse research trends on geography teaching on ESD in the context of AGE-National and Iberian conference proceedings and the journal Didáctica Geográfica from 1988. To select the keywords for the screening, we selected terms representative of each article's contents from the abstracts or, failing this, from the main body of the text. The terms used in the preliminary tag clouds were used as reference in order to homogenise the terminology as much as possible. Afterwards, the selected terms were manually depurated to avoid bias, based on the detailed examination of the content of each article and following the guidelines set out by the actantial analysis.

\subsection{Results}

This section presents the analysis and assessment of ESD-related research in the context of AGE in detail. However, before doing so, it is worth recalling the relevant role played by ESD teaching in Spanish geography.

Table 1 illustrates the terms used in the titles of at least $2 \%$ of the 1369 inventoried bibliographic items. As shown, the main fields of interest in recent research on geography teaching are teaching skills ("training", "teacher", "teaching"), the use of innovative teaching technologies and techniques ("application", "ICT", "innovation", "proposal"), and the didactic strategies, contents, resources and proposals deployed in teaching ("curriculum", "resource", "school"). In addition to these three categories, there is a substantial interest in "landscape" and the "environment", which emphasises Spanish geography's concern for sustainability and the preservation of the geographical medium. 
Table 1. Terms (translated from the Spanish) used in at least 28 of the 1369 items inventoried (2\% of the total).

\begin{tabular}{|c|c|}
\hline RECURRENCE & TERMS (Number of Appearances) \\
\hline$\geq 20 \%$ & Geography (639); education (414); teaching (294); didactic (285) \\
\hline $10-20 \%$ & Geographic (186); landscape (157) \\
\hline & School (132); learning (123); proposal (104); resource (103); \\
\hline $5-10 \%$ & $\begin{array}{l}\text { teacher (100); training (84); study (84); environment (77); primary (76); social (76); } \\
\text { city (74); secondary (69) }\end{array}$ \\
\hline $2-5 \%$ & $\begin{array}{l}\text { Rural (66); experience (65); space (65); students (65); urban (59); environmental (58); } \\
\text { curriculum (57); maps (56); university (55); analysis (54); development (52); } \\
\text { knowledge (52); sciences (52); } \\
\text { ESO (52); works (52); classroom (46); natural (45); } \\
\text { innovation (44); practice (43); itinerary (43); Spain (42); methodological (41); area } \\
\text { (40); project (40); active (40); } \\
\text { values (40); research (38); application (36); field (35); contributions (35); territory (34); } \\
\text { ICT (31); interpretation (31); early (31); concept (30); citizenship (29); } \\
\text { teaching-learning (29); textbooks (29); initial (28); competences (28) }\end{array}$ \\
\hline
\end{tabular}

Terms (translated from the Spanish) used in at least 28 of the items inventoried ( $2 \%$ of the total)-AGE

conference proceedings and journal Didáctica Geográfica. Authors' own with data from TagCrowd.

The following section presents the result of using the application VOSviewer to analyse the fields of interest of ESD-related research in geography teaching in Spain and the evolution of bibliographic interests of authors.

\subsubsection{Fields of Interest of ESD-Related Research}

As noted, the software VOSviewer was used to generate concept maps that represent the interests of the relevant authors. Using as reference terms included in at least three or more of the ESD-related items (Figure 2) and their connections (they co-occur in the same title), the interest for the development of an educational framework that raises awareness among students ("didactic", "innovation", "case"), and the prominent place held by environmental and rural contexts ("environment", "environmental", "rural"), become immediately noticeable. The map also reveals some emphasis on geographyspecific aspects of sustainability, such as "mobility" and the social component ("social").

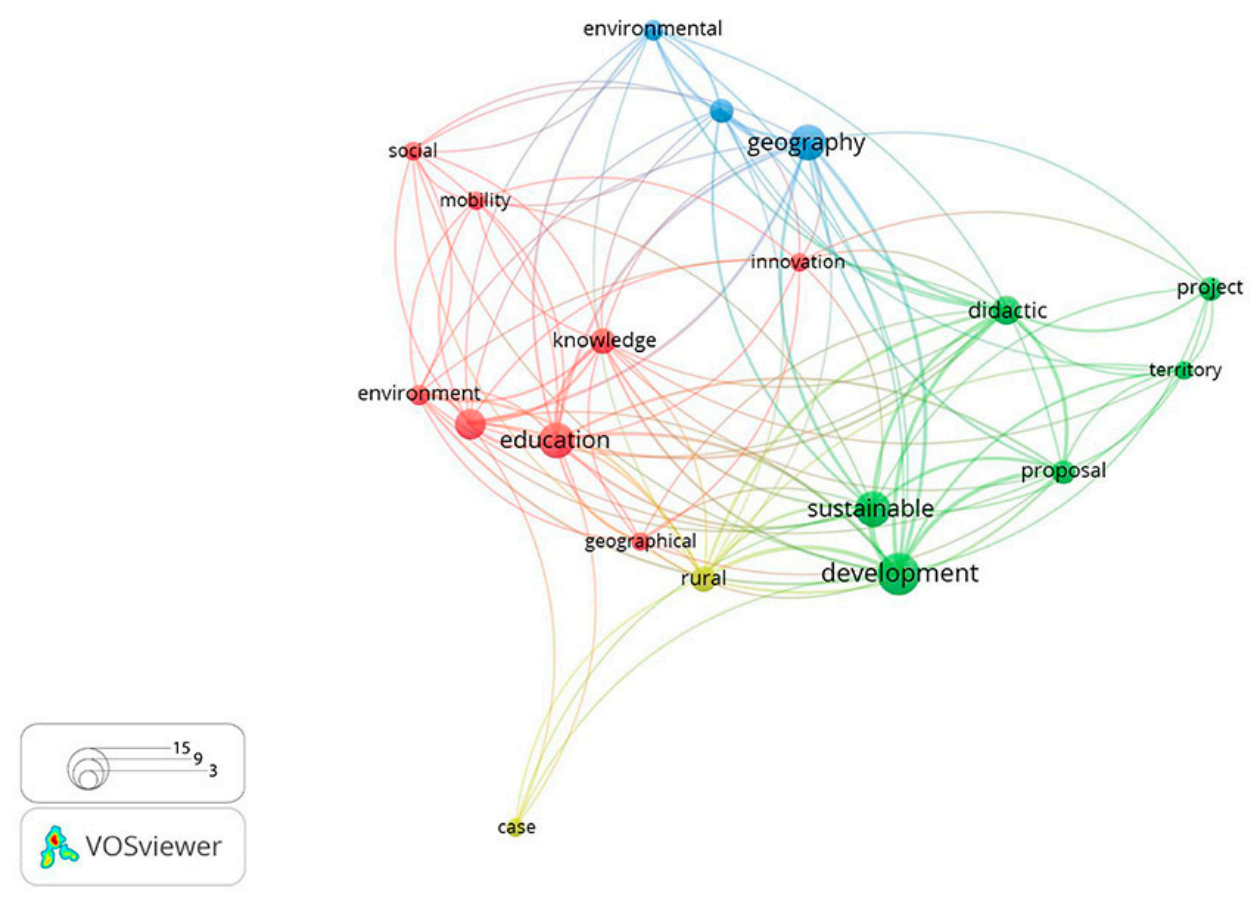

Figure 2. Correlation map of terms that feature in the titles of three or more items. The size of the circles represents the recurrence of each term. The colours correspond to clusters of oft-related article keywords. 
The relational map of keywords (Figure 3) betrays considerable interest on teaching practices, and several contributions emphasise the importance of including ESD in curricula and of ensuring the availability of the necessary materials ("curriculum", "textbooks", "cartography" are found in relation to one another two times or more); also of interest are didactic practices ("didactic", "school" / "class", "training", "project" are found together recurrently); and the lateral nature of geographical concepts related to sustainable development ("mobility", "landscape", "interculturality", "citizen", "values", etc., are found in association with interrelated subjects).

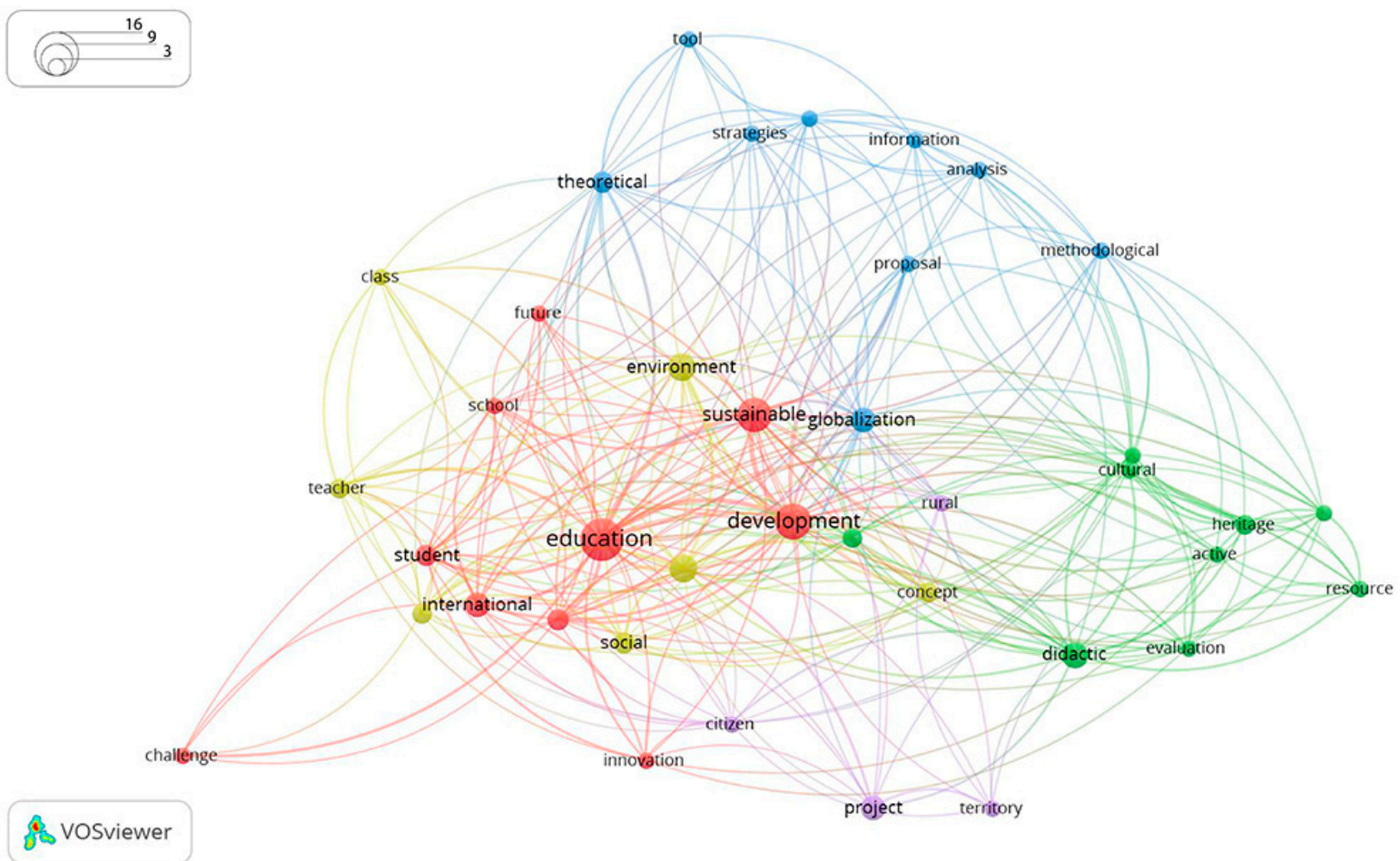

Figure 3. Correlation of keywords featured in three or more items. The colours correspond to clusters of oft-related article keywords.

On the other hand, the selected keywords reveal the multiplicity of approaches adopted by ESD-related research in Spanish geography, especially concerning fields of interest such as architecture, tourism and heritage (specifically, heritage is addressed in a wide variety of studies, which highlights the central role played by ESD in the preservation of territorial heritage, which is a major feature in Spain). The lateral nature of ESD is, therefore, clearly expressed, as is its growing importance as reference for geography teaching in a changing world ("international", "globalization", "identity", "values").

The diversity of fields of interest identified with VOSviewer reflects the multiple approaches to ESD in Spain, but also the lack of a series of core topics able of attracting a significant number of researchers. However, as we shall see shortly, some thematic and epistemological trends can be outlined.

\subsubsection{Evolution over Time of ESD-Related Research}

VOSviewer can be used to track the evolution of research interests by calculating the average publication year of each term based on its concurrence in titles and keywords. As shown in Figure 4, the earliest publications to specifically address the issue at hand are dated to 2003, and they initially focused on the development of teaching proposals for ESD and the conceptualisation of the term "sustainable development" in the framework of teaching practices. This reveals that Spanish geography came late to ESD-related research, which was by then a fully established field in other European countries. The profound challenges faced by Spanish education-five education reform acts have been passed in 
barely 30 years-could go a long way to explain the backwardness of Spanish education vis-à-vis its neighbours in the debate and design of ground-breaking topics such as ESD and digital skills.

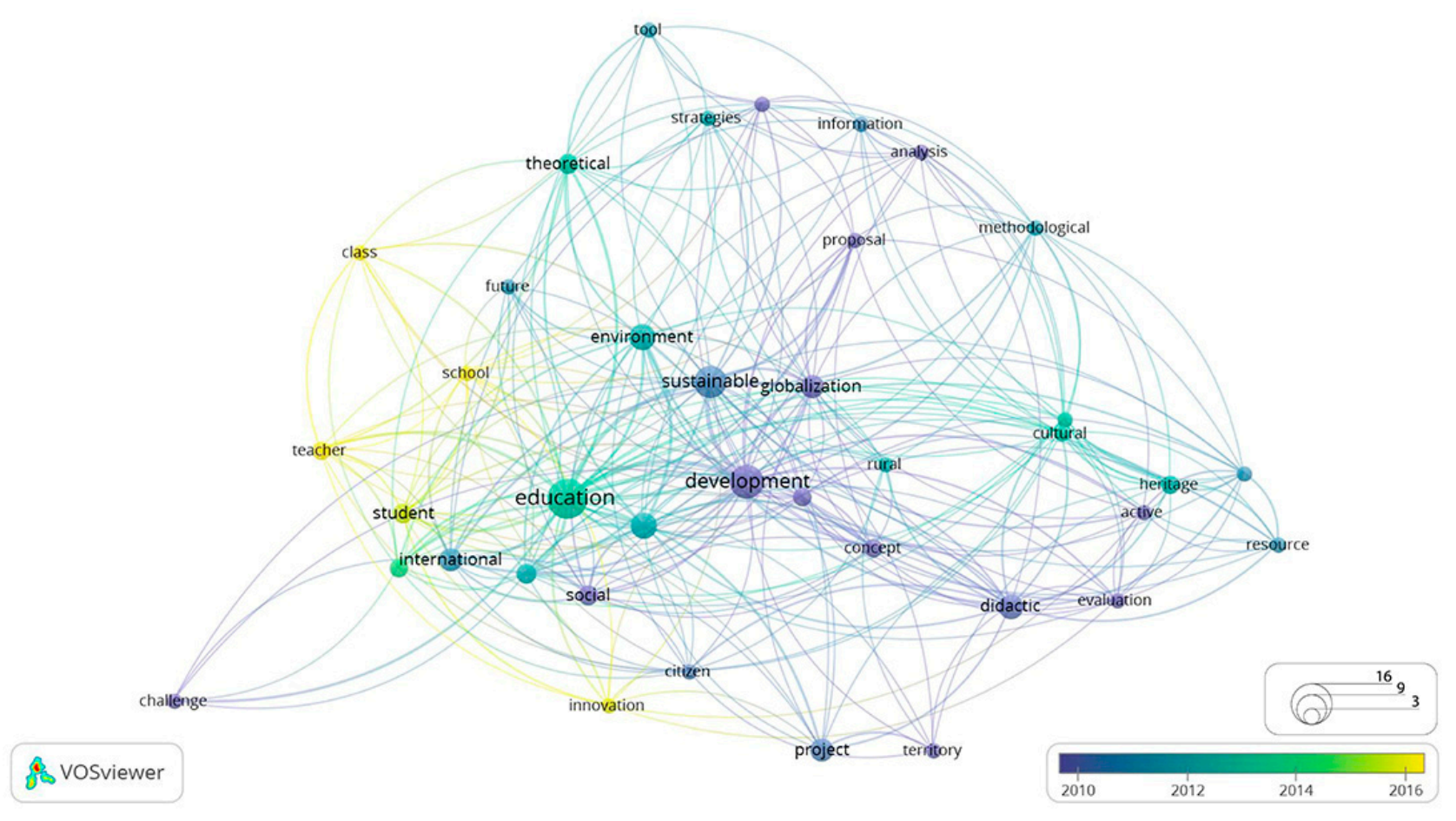

Figure 4. Correlations between keywords that feature in three or more items, with information concerning their average publication year, based on the publication date of the items in which they feature.

As illustrated by Figure 4, in recent years, the publications tend to focus more on ESD-related teaching-learning processes and on raising the awareness of students about specific issues, such as mobility, culture and heritage, as well as on innovation in teaching methods. This suggests an interest in answering traditional questions in the field of research on education: what to teach and how. On the other hand, some correspondence can be attested between research topics and the statements issued by the IGU, for instance, a substantial increase in ESD-related research in the years following the Lucerne declaration, or the growing presence of such terms as 'innovation', 'students' and 'school' after the 2016 statement, in which these terms were emphasised.

Finally, Figure 5 illustrates clusters of terms used in the selected titles and publications. Clusters are nodes of closely-related terms and, depending on the type of link under analysis, each node is assigned to a specific cluster [25] in order to define groups of interest (GI). Four major groups of interest can be found in Spanish ESD-related research in geography. First (GI 1), methodology, which deals with the design of didactic tools and strategies; second (GI 2), the selection of teaching contents and their relation to the curriculum in each stage of education; third (GI 3), teaching practices, taking into account the training of both students and teachers, as well as the design of specific teaching activities; finally (GI 4), lateral ESD-related approaches, including issues such as culture, heritage, teaching innovation and marking. 


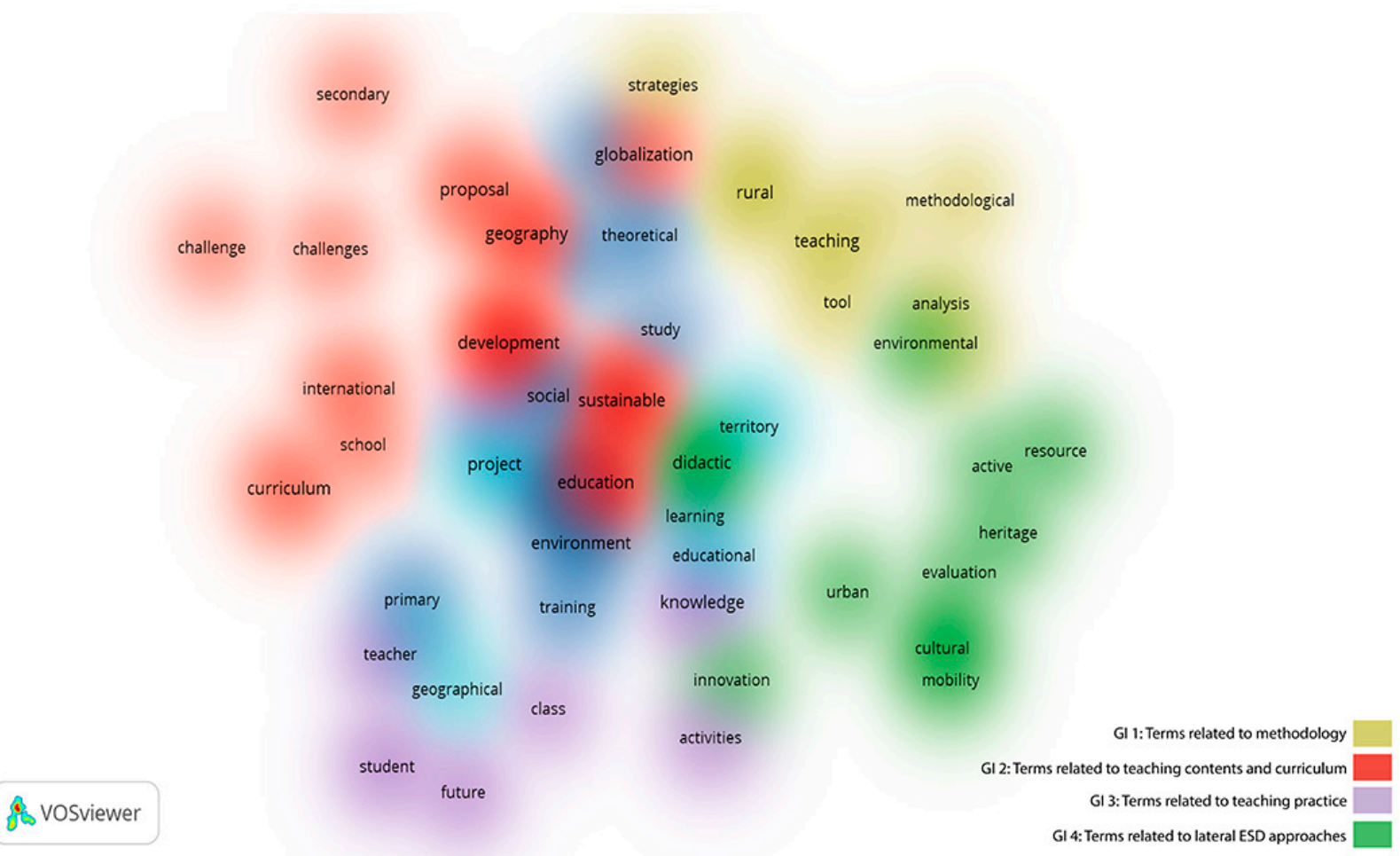

Figure 5. Clusters of recurrent terms in titles and keywords that feature in three or more items. Each colour represents a cluster of topics jointly addressed in several research works. The terms in blue are associated with two or more clusters simultaneously.

\subsubsection{Perspective of Spanish ESD-Related Geographical Research}

The bibliography cited by the authors of the selected items illustrates trends in ESD-related geographical research in Spain. Figure 6 shows the recurrence of mentions cited by two or more publications, indicating, when applicable, co-occurrence with other mentions. This indicates the position and growth of ESD as a topic of research in the didactics of geography. The figure and the qualitative analysis of the references lead to two main conclusions:

- Although over the past decade Spanish authors have developed a significant theoretical, strategic and experimental framework - especially relevant authors in this regard are Souto [12,26,27], Marrón [28], De Lázaro [29-31], Granados [32,33], González and Lázaro [34,35], Jerez [36,37], De Miguel [12,38] and Rodríguez Domenech [39,40]—-there is still great interest for the work of foreign authors. We could speak of the growing internationalisation of Spanish ESD-related research, both in terms of SDGs and different European sustainability-related initiatives.

- There is a growing interest in ESD among specialists in geography teaching. In this sense, it can be said that ESD is now a consolidated avenue of research for many research groups that specialise in the didactics of geography; in contrast with some years ago, when the issue was mostly approached by individual researchers, a recent increase in the number of publications linked with innovation projects is attested, and this is also reflected in the increasing number of multi-authored works. 


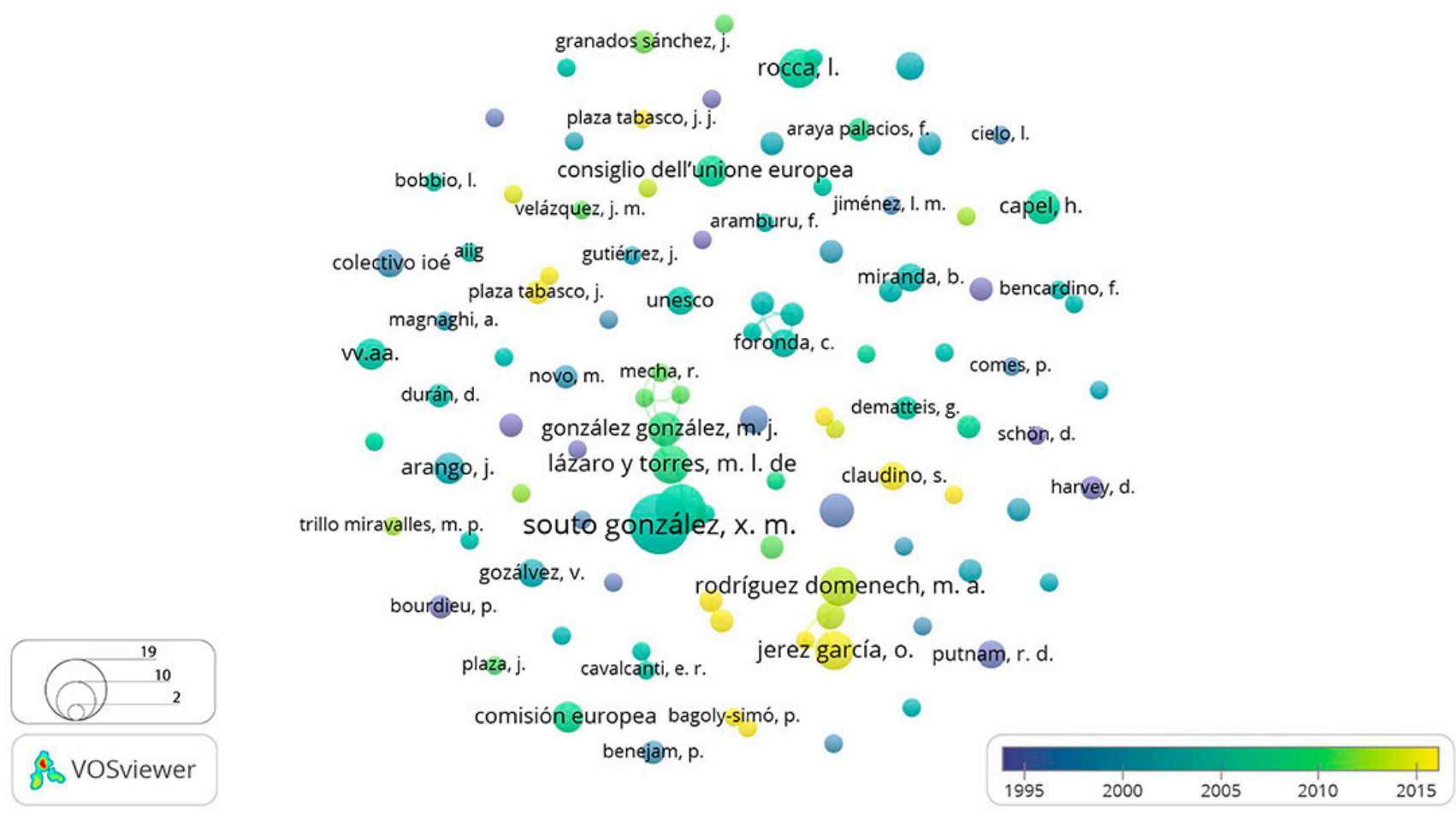

Figure 6. Authors cited in two or more of the selected publications and correlated citations with indication of the average year of publication of the works cited.

\section{Discussion}

There is little doubt that the adoption of ESD in geography cannot be limited to the revision of contents and lateral activities. If we want students to acquire the necessary knowledge and gain the required skills, ESD must be incorporated in every educational level, particularly to Spanish school curricula, much more organically. In Spain, despite the large number of ESD-related geographical initiatives in place, explicit references to these in curricula remain rare. In recent years, a number of specific activities and even subjects around this issue have been implemented in secondary schools (in the region of Galicia, for instance, secondary schools offer an optional module entitled "Paisaxe e Sustentabilidade" - Landscape \& Sustainability — which aims to strengthen the teaching of ESD), but it is legitimate to wonder if ESD will eventually become a primary concern of geography teaching [41] and, by extension, of related research. We do not believe that the didactics of geography must focus exclusively on ESD, but in order to encourage a critical approach to our changing world and its circumstances, we believe that ESD should acquire an increasingly relevant role in all fields of geographical research, as emphasised by various IGU declarations. In the frame of research on the didactics of Geography, our work reveals that ESD-related research in geography is undergoing a critical transformation towards the development of theoretical and methodological proposals that promote critical awareness and concern about sustainable development among students. To date progress, remains slow, too slow, especially considering SDGs, but steady. Thus, results suggest that IGU statements and the topics chosen for the Iberian and Spanish conferences have some impact on research. In this regard, the recent 23rd AGE's Congress of Didactics of Geography, "Enseñar y aprender geografía para un mundo sostenible" (Teaching and Learning Geography for a Sustainable World), held in Girona on 19 and 20 March 2021 (owing to the COVID-19 pandemic the conference was held online and postponed from October 2020 to the cited date), has become the first conference on geography teaching to deal specifically with sustainability and ESD in Spain. The manuscripts submitted to this event were not considered in this article because they had not been published by the time the manuscript was submitted, but it can potentially be a turning point for the promotion 
of ESD in the country. The review of the 55 contributions presented at the event reveals that over half $(51 \%)$ focused directly on ESD-related issues, while the rest addressed more traditional topics, such as geographical teaching-learning, ICTs and the role of fieldwork in geography teaching (Table 2). We shall see whether this event becomes a real turning point that promotes new trends and proposals in research on Spanish geography teaching or remains an isolated event with little impact, as has been the case with previous conferences.

Table 2. Conference contribution by topic (Girona, 2021).

\begin{tabular}{cc}
\hline Topic & Number of Contributions \\
\hline 1. Integration of sustainable development and education for & 6 \\
sustainability in geography teaching & 8 \\
2. Climate change and sustainable development targets & 7 \\
3. The role of geography in the construction of global & 7 \\
sustainable citizenship & 7 \\
4. The didactics of sustainable landscapes & 7 \\
5. Powerful geographical knowledge & 7 \\
6. Teaching and learning geography & 6 \\
7. Digital geography teaching before and after COVID-19 & 55 \\
8. The role of fieldwork in geography teaching & Total
\end{tabular}

Contributions by topic from the programme of I Congreso Internacional y XIII Nacional de Didáctica de la Geografía de la AGE: "Enseñar y aprender geografía para un mundo sostenible" (Teaching and learning Geography for a sustainable world).

As noted in the methodology section, the aim of this bibliographic review was to outline the main trends and interests in ESD-related research in Spain, based on the scientific production linked to the didactic group at AGE. We understand that this approach imposes some limitations on our research. First, a number of Spanish authors and researchers on the teaching of ESD in Geography have been publishing primarily in international specialised journals for some time now [42,43]. Second, we are aware that there are other ESD fora in which Spanish geographers participate whose identification and analysis is especially difficult considering the lateral nature of ESD. In this regard, we expect that future research will analyse these works and compare trends with those detected within the framework of the AGE.

Regarding the bibliographical analysis, the fact that Spanish geographic academic publications about Geography teaching are not included in WoS or Scopus hinders not only the visibility of Spanish research groups, but also makes it difficult to evaluate the real state of the art of ESD research in Spain. Additionally, publications keywords selection bias for VOSviewer analysis (see Section 3.1) might imply that our bibliographical analysis does not identify all relevant terms for the Spanish contribution to ESD research. In any case, we believe that this study outlines the scope of ESD-related research in Spanish geographic academic institutions. The items selected illustrates the growing interest of this topic among Spanish geographers, despite its belated consolidation as a research field in the country, as well as the wide variety of research interests pursued; this is in line with the very idiosyncrasy of Spain, a country characterised by heterogeneous landscapes and heritage, and also with the evolution of the Spanish education system, which has undergone constant shifts in terms of curricula and legislation. This comes on top of the frail foundations of geography as an academic field, the absence of specific channels and fora on the didactics of geography and ESD until recent times, the prevalence of other research priorities and, until very recently, little interest in SDG, which has meant that Spain lags behind other countries in terms of the priority given to this issue (as previously noted, countries such as the United Kingdom, France or Sweden have included environmental education and sustainability didactics in their school curricula for more than 50 years).

Geography teaching research in Spain needs to undergo significant changes in order to adequately address current educational challenges and promote the role of the discipline in ESD. In addition to the continued promotion of research in the field, it is urgent 
for teachers and researchers to become aware of the importance of teaching sustainable development to future generations, and of the central role that geography can play in this, owing to its nature as a lateral subject, which is key for sustainable development and environmental protection.

\section{Conclusions}

It seems clear that ESD is taking an increasingly prominent role in geography teaching. Different initiatives for the promotion of ESD, especially in the wake of the growing interest in SDGs, are being put forward, and the community of geographers is committed to innovate in terms of contents, skills and activities.

This is facilitated by the obvious suitability of geography as a discipline for the promotion of ESD, especially in recent years. The methodological changes undergone by the teaching of the discipline with the development of GITs and new active methodologies, as well as a renewed interest in fieldwork, have greatly improved the potential of geography teaching in terms of ESD insofar as the discipline makes students keenly aware, in an eminently practical way, of the importance of preserving the geographical environment and the peremptory need for a social and ecological transition to cope with current challenges, such as climate change and the overexploitation of natural resources.

The effects of climate change and growing disputes for the control of natural resources, topics which are central for geography, create an ideal environment for the discipline to turn out students who are sensitive, critical and aware of current challenges. It is expected that, in a world that changes increasingly fast, geography will become more and more important in the education of citizen-students in all stages of education, taking a growing role in ESD.

This study has shown that, despite the significant progress made over the last five years, geography teaching for ESD in Spain still has a long way to go. At any rate, it seems clear that research interest around this issue is growing, as shown by the fact that it is increasingly regarded as a research field of reference for groups, journals and conferences. The recent conference in Girona might be a stimulus for ESD in geography teaching in Spain, and we hope that the internationalisation of Spanish research will open new avenues and horizons in which the topic is paid the attention that it deserves.

Supplementary Materials: The following are available online at https:/ / www.mdpi.com/article/10.339 0/su132313118/s1 and https:/ / zenodo.org/record/5571023\#.YYEYip7MJpk (accessed on 15 October 2021).

Author Contributions: This work is a choral undertaking, and all three authors have contributed to it in equal measure. Conceptualization, M.R.M.G., A.R.d.C. and J.M.C.C.; methodology, A.R.d.C., J.M.C.C. and M.R.M.G.; software, A.R.d.C., J.M.C.C. and M.R.M.G.; validation, J.M.C.C., M.R.M.G. and A.R.d.C.; formal analysis, M.R.M.G., A.R.d.C. and J.M.C.C.; investigation, A.R.d.C., J.M.C.C. and M.R.M.G.; resources, M.R.M.G., A.R.d.C. and J.M.C.C.; data curation, J.M.C.C., M.R.M.G. and A.R.d.C.; writing-original draft preparation, A.R.d.C., J.M.C.C. and M.R.M.G.; writing-review and editing, J.M.C.C., M.R.M.G. and A.R.d.C.; visualization, A.R.d.C., J.M.C.C. and M.R.M.G.; supervision, M.R.M.G., A.R.d.C. and J.M.C.C.; project administration, J.M.C.C., M.R.M.G. and A.R.d.C.; funding acquisition, J.M.C.C., M.R.M.G. and A.R.d.C. All authors have read and agreed to the published version of the manuscript.

Funding: The APC was funded by GEODIDAC research group (Complutense University of Madrid).

Data Availability Statement: The data presented in this study are public and available in https: / / zenodo.org/record/5571023\#.YYEYip7MJpk (accessed on 15 October 2021).

Conflicts of Interest: The authors declare no conflict of interest.

\section{References}

1. Novo, M. La Educación Ambiental. Bases Éticas, Conceptuales y Metodológicas; UNESCO/Universitas: Madrid, Spain, 1998; pp. 1-276.

2. Zabala, I.; García, I. Historia de la Educación Ambiental Desde su Discusión y Análisis en Los Congresos Internacionales. Revista de Investigación. 2008. Available online: http:/ /ve.scielo.org/scielo.php?script=sci_arttext\&pid=S1010-29142008000100011\& lng=es\&nrm=iso\&tlng=es (accessed on 15 October 2021). 
3. Novo, M. La Educación Ambiental, Una Genuina Educación Para el Desarrollo Sostenible. Revista de Educación. 2009. Available online: http:/ / www.revistaeducacion.mec.es/re2009/re2009_09.pdf (accessed on 15 October 2021).

4. The World Commission on Environment and Development. Our Common Future. 1987. Available online: http://www.undocuments.net/wced-ocf.htm (accessed on 15 October 2021).

5. UNESCO. Década de las Naciones Unidas de la Educación para el Desarrollo Sostenible. 2005. Available online: https://es. unesco.org/themes/educacion-desarrollo-sostenible/comprender-EDS/decenio-onu; https://en.unesco.org/themes/educationsustainable-development/what-is-esd/un-decade-of-esd (accessed on 15 October 2021).

6. Bertero, M. Decenio de la Educación para el Desarrollo Sostenible. 2006. Available online: https://www.unescoetxea.org/ dokumentuak/Conferencia_Bertero.pdf (accessed on 15 October 2021).

7. Comisión de Educación Geográfica. Unión Internacional de Geografía. Declaración Internacional Sobre Educación Geográfica. 1992. Available online: https://core.ac.uk/download/pdf/39036329.pdf; http:/ /www.igu-cge.org/wp-content/uploads/20 18/02/1.-English.pdf (accessed on 15 October 2021).

8. IGU Commission on Geographical Education. International Declaration on Geographical Education for Cultural Diversity. 2000. Available online: http://www.igu-cge.org/wp-content/uploads/2018/02/Declaration-cultural.pdf (accessed on 15 October 2021).

9. Comisión de Educación Geográfica. Unión Internacional de Geografía. Declaración Sobre Educación Geográfica para el Desarrollo Sostenible. 2007. Available online: https://www.igu-cge.org/wp-content/uploads/2018/02/spanish.pdf; https: //www.igu-cge.org/wp-content/uploads/2018/02/Luzern_Gesamtdokument_Band_42_101007.pdf (accessed on 15 October 2021).

10. de Miguel, R.; Van der Schee, J. Declaración Internacional Sobre Investigación en Educación Geográfica. Didáctica Geográfica. 2015. Available online: https:/ / didacticageografica.age-geografia.es/index.php/didacticageografica/article/view/27 8; https:/ / www.igu-cge.org/wp-content/uploads/2018/02/International-Declaration-on-Research-in-Geography-EducationFULL-DOCUMENT-JUNE-2015.pdf (accessed on 15 October 2021).

11. Kolossov, V. Declaración Internacional Sobre Educación Geográfica. Didáctica Geográfica. 2017. Available online: https:// didacticageografica.age-geografia.es/index.php/didacticageografica/article/view/354; https://www.igu-cge.org/wp-content/ uploads/2019/03/IGU_2016_eng_ver25Feb2019.pdf (accessed on 15 October 2021).

12. De Miguel, R.; Claudino, S.; Souto, X.M. La Utopía de la Educación Geográfica en las Declaraciones Internacionales de la UGI. XIV Coloquio Internacional de Geo-crítica. Las Utopías y la Construcción de la Sociedad del Futuro. Geocrítica. 2016. Available online: http:/ / www.ub.edu/geocrit/xiv_demiguel_claudino.pdf. (accessed on 15 October 2021).

13. Asociación de Geógrafos Españoles. Declaración Conjunta del Colegio de Geógrafos de España y la Asociación Española de Geografía (AGE) Ante la Propuesta de Incluir Una Asignatura de Cambio Climático en la Enseñanza no Universitaria de Nuestro País. 2019, pp. 1-2. Available online: https://www.age-geografia.es/site/wp-content/uploads/2019/12/DECLARACI\%C3\%9 3N-CONJUNTA-DEL-COLEGIO-DE-GE\%C3\%93GRAFOS-DE-ESPA\%C3\%91A-Y-DE-LA-ASOCIACI\%C3\%93N-ESPA\%C3 \%91OLA-DE-GEOGRAF\%C3\%8DA-def.pdf (accessed on 15 October 2021).

14. Toro, F.J. La geografía como un saber necesario para la sostenibilidad: Consideraciones a propósito de las propuestas educativas de Edgar Morin. Cuad. Geográficos. 2011, 49, 9-32. [CrossRef]

15. Busquets, J. La Importancia de la Educación en Paisaje. Available online: http://www.catpaisatge.net/esp/documentacio_plecs_ ref_2.php (accessed on 15 October 2021).

16. García de la Vega, A. El Itinerario Geográfico Como Recurso Didáctico para la Valoración del Paisaje. Didáctica Geográfica. 2004. Available online: https:/ / didacticageografica.age-geografia.es/index.php/didacticageografica/article/view/182 (accessed on 15 October 2021).

17. Casas-Jericó, M.; i Baguer, J.P.; Altarriba, L.E. El "paisaje” como recurso para la Educación Ambiental. Experiencia práctica en el Equipamiento "Sendaviva" (Navarra). Obs. Medioambient. 2017, 20, 111-136. [CrossRef]

18. Crespo, J.M. Un Itinerario Didáctico para la Interpretación de Los Elementos Físicos de la Sierra de Guadarrama. Didáctica Geográfica. 2012. Available online: https:/ / didacticageografica.age-geografia.es/index.php/didacticageografica/article/view / 94 (accessed on 15 October 2021).

19. Crespo, J.M.; Rodríguez de Castro, A. Las Tecnologías de la Información Geográfica y su Contribución al Desarrollo de la Competencia Digital Docente. El Uso Didáctico del Visualizador Iberpix. 2019. Available online: https://www.age-geografia.es/site/ la-reconfiguracion-del-medio-rural-en-la-sociedad-de-la-informacion-nuevos-desafios-en-la-educacion-geografica/ (accessed on 15 October 2021).

20. Burriel, E.L. La Licenciatura de Geografía en la Universidad Española Actual. 2004. Available online: https: / / realsociedadgeografica. com/wp-content/uploads/2018/02/geografia_castellano.pdf (accessed on 15 October 2021).

21. Fernández, L.C.M.; Urrecho, J.M.D. La Geografía en las enseñanzas universitarias de Grado en España: Docencia y planes de estudios. Investig. Geográficas 2017, 67, 61. [CrossRef]

22. Asociación de Geógrafos Españoles. Available online: https://www.age-geografia.es/site/quienes-somos/ (accessed on 15 October 2021).

23. Hallinger, P.; Chatpinyakoop, C. A Bibliometric Review of Research on Higher Education for Sustainable Development, 1998-2018. Sustainability 2019, 11, 2401. [CrossRef] 
24. Grosseck, G.; Tîru, L.G.; Bran, R.A. Education for Sustainable Development: Evolution and Perspectives: A Bibliometric Review of Research, 1992-2018. Sustainability 2019, 11, 6136. [CrossRef]

25. Limaymanta, C.H. El Mapeo Científico con VOSviewer: Un Ejemplo con Datos de WoS. Otlet, Perspectivas. 2020. Available online: http:/ / www.revistaotlet.com/tips-cesar-limaymanta-mapeo-cientifico-con-vosviewer/ (accessed on 15 October 2021).

26. Souto, X.M. Educación Geográfica y Ciudadanía. Didáctica Geográfica. 2007. Available online: https:/ / didacticageografica.agegeografia.es/index.php/didacticageografica/article/view/2 (accessed on 15 October 2021).

27. Souto, X.M. La geografía escolar: Deseos institucionales y vivencias de aula. BAGE 2018, 79. [CrossRef]

28. Marrón, M.J. Desarrollo sostenible, globalización y educación en valores ambientales desde la Geografía. Una propuesta metodológica en el marco europeo de educación superior. In Las Competencias Geográficas para la Educación Ciudadana; Marrón, M.J., Salom Carrasco, J., Souto González, X.M., Eds.; Universidad de Valencia: Valencia, Spain, 2007; pp. $133-146$.

29. De Lázaro, M.L. Educar para el desarrollo sostenible desde la Geografía. In Aportaciones de la Geografía en el Aprendizaje a lo Largo de la Vida; Universidad de Málaga: Málaga, Spain, 2011; pp. 11-26.

30. De Lázaro, M.L.; Roda, E.M.; Morales, F.J. SIGWeb, Una Herramienta para Integrar los Objetivos de Desarrollo Sostenible en las Asignaturas de Geografía en la UNED. Available online: https:/ / dialnet.unirioja.es/servlet/articulo?codigo=7146209 (accessed on 15 October 2021).

31. De Lázaro, M.L. SIGWeb para Educar en los Objetivos de Desarrollo Sostenible. UNED. 2018. Available online: https:/ / canal. uned.es/trackfile/5b0bf3cfb1111fff518b4567.mp4 (accessed on 15 October 2021).

32. Granados, J. Niveles de sostenibilización curricular para una didáctica de la geografía transformadora. In Enseñar y Aprender Geografía para un Mundo Sostenible; Octaedro: Girona, Spain, 2021.

33. Granados, J. Conceptualización de la ciudadanía sostenible desde el realismo social crítico. In Enseñar y Aprender Geografía para un Mundo Sostenible; Octaedro: Girona, Spain, 2021.

34. González, M.J.; Lázaro, M.L. Los Hitos y los Retos del Desarrollo Sostenible en la Planificación Urbana. Available online: http://www.fundicotex.org/TCDS/Estructura\%20de\%20CD/Comunicaciones/Com_Bloque\%20I_TERRITORIOS_1/ Gonzalez\&DeLazaro.pdf. (accessed on 15 October 2021).

35. González, M.J.; Lázaro, M.L. Urban Development and Sustainability. European Journal of Geography. Available online: http:/ / www.eurogeographyjournal.eu/showPaper.php?id=138 (accessed on 15 October 2021).

36. Serrano, M.A.; Garcióa, J.L.; Jerez, O. Propuesta Preliminar para la Identificacioón de Lugares de Intereós Didaóctico en Espacios Naturales Protegidos. Didáctica Geográfica. Available online: https:/ / didacticageografica.age-geografia.es/index.php/ didacticageografica/article/view/364 (accessed on 15 October 2021).

37. Jerez, O. La Transferencia de Conocimientos Didáctico-Geográficos en el Medio Rural. El Senderismo Didáctico Como Propuesta para un Desarrollo Rural sostenible. In La Reconfiguración del Medio Rural en la Sociedad de la Información; En Carlos, X., Armas, F.X., y Rodríguez, F., Coords, Eds.; Andavira Editora: Lugo, Spain, 2019.

38. De Miguel, R. Geografía y tiempo contemporáneo: Educación geográfica y enseñanza de las ciencias sociales para el mundo global. REIDICS. J. Res. Didact. Soc. Sci. 2018, 2, 36-54. [CrossRef]

39. Rodríguez, M.A.; Espinosa, E.M.M.; Jerez, Ó. ¡Nosotros Proponemos, Ciudad Real! Ciudadanía, Sostenibilidad e Innovación en la Educación Geográfica. In: Educaçáo Geográfica na Modernidade Líquida. Cámara, A.C. y Sande, E. Coords. Plátano Editora. Lisboa, Portugal. Available online: https:/ / dialnet.unirioja.es/servlet/articulo?codigo=7856028 (accessed on 15 October 2021).

40. Rodríguez, M.A.; Campo, B. Soluciones escolares a los problemas ciudadanos: La experiencia de “iNosotros proponemos!”. Íber Didáctica de las Cienc. Soc. Geogr. e Historia. 2018, 93, 22-28.

41. Granados, J.; Medir, R.M. Enseñar y Aprender Geografía para un Mundo Sostenible; Octaedro: Barcelona, Spain, 2021; pp. 9-14.

42. Ramírez-Verdugo, M.D.; de la Vega, A.G. A Conceptual Reference Framework for Sustainability Education in Multilingual and Cross-Cultural Settings. In Designing, Constructing, and Programming Robots for Learning; IGI Global: Hershey, PA, USA, 2018; pp. 222-236.

43. Granados, J. The Contribution of Geography Teachers to Education for Sustainability: A case Study. In Changing Horizons in Geography Education. Herodot Network. Torún; Donert, K., Charzyński, P., Eds.; Available online: https: / / repozytorium.umk.pl/ bitstream/handle/item/351/Changing\%20Horizons.pdf?sequence=2\#page=305 (accessed on 15 October 2021). 